\title{
Student Life at the College of The Bahamas: The Role of COBUS
}

\section{DeAndra V. Cartwright Youth Advocate ${ }^{1}$}

\section{ABSTRACT}

Student government and student activities at the College of The Bahamas have helped to define the growth and development of the institution. The College of the Bahamas Union of Students or COBUS as it is better known, has been a crucible for civic and professional leaders. Many COBUS Presidents have gone on to become leaders in the community, well-known forerunners in their respective fields of endeavour and have become household names in the Bahamas.

\section{INTRODUCTION}

The College of The Bahamas has existed for 40 years, during which time, the institution and its faculty, staff and students have witnessed many changes. While some aspects of the College's history have been written, a history of its student life has not been welldocumented. Unfortunately information about the development of student life since the inception of the College could only be gleaned from copies of the student newspaper, The Spectrum, of which only a few physical and digital copies have survived.

Student concerns today tend to be centered on issues of security, college programmes and courses, faculty, resources, and the timeless debate about the College attaining university status. Some of these concerns have been going on for quite some time - having been expressed in the 1970s and 1980s.

Bahamian historian Dr Gail Saunders and COB President Emeritus Dr Keva Bethel, both of whom have documented the development of education in The Bahamas, have been cited in recent publications for their emphasis on the imperative of knowing and understanding our history (Farmer, 2011). This is true in relation to the student life at the College of the Bahamas as such a history allows us to understand the evolution of student life and student advocacy within the institution.

The Spectrum newspaper was the primary source for documenting student life and student government at COB. Although the student newspaper began publication in about 1983, the earliest edition available in hard copy in the College's Archives is from 1986. Former editor of the newspaper, Jasper Haeward, made the move to have the periodical published online in 2011 because The Spectrum faced financial challenges in the mid-2000s. The Library and Media Information Services department of the College has since begun scanning back issues and making them available electronically.

\footnotetext{
${ }^{1}$ DeAndra V. Cartwright, Youth Advocate, The College of The Bahamas.

E-mail: dvcartwright@yahoo.com

APA reference: Cartwright, D. V. (2014). Student life at the College of the Bahamas and the role of COBUS. International Journal of Bahamian Studies, 20(2), 19-25.

https://doi.org/10.15362/ijbs.v20i2.244
}

(C) D. V. Cartwright, 2014. Journal compilation @ The International Journal of Bahamian Studies, 2014 
The College has achieved much in these past 40 years, during which time, the student body has attained some important milestones; yet some of these successes seem to have slipped the mind of not only the students and alumni of the College but also of the wider Bahamian public.

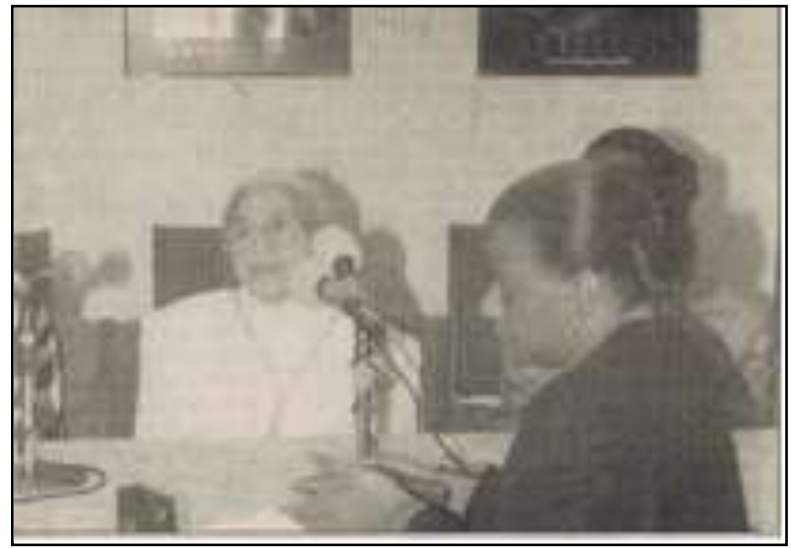

For example, who remembers that the African American civil rights activist, Ms. Rosa Parks, was interviewed by a COB staff member, Mavis Johnson (Hall, 1996) while visiting The Bahamas to promote her book, Quiet
Strength? Who remembered, also, while our country expressed its condolences to South Africa and to the family of the late Nelson Mandela, its first black president, that, this empowering man visited COB's campus and sat with students?

Further, while we remember visits by various heads of state to the College, we recall also that the Head of the Commonwealth of The Bahamas, Queen Elizabeth II,

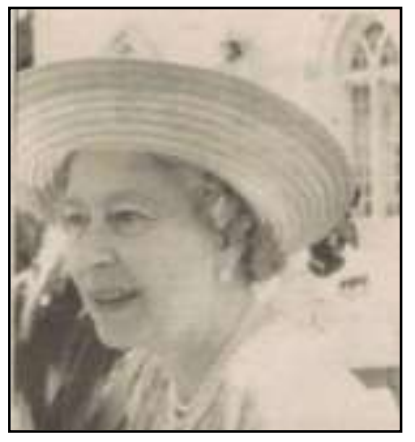
also walked the hallowed halls of College of The Bahamas when she officially opened the Bahamas Hotel Training College (Davis, 1994). The country's first Prime Minister, Sir Lynden Pindling gave special lectures to the students in the early years of the College.



An eastern view of the Student Union Building and the B \& T Blocks Source: Author's Personal Archive

Student governments go through cycles of varying degrees of engagement. Sometimes the leadership is moderately involved, while at other times it delves into the issues facing students. COB's student body is not different. When it comes to matters pertaining to classes, course availability, fees and tuition increase, students have spoken very loudly, and COBUS has taken up their concerns and worked toward achieving resolutions. The latest student demonstration occurred in April 2013, which was the culmination of a series of 
events resulting from the proposed increase in tuition and specific standing fees along with the introduction of additional fees. The proposed financial adjustments were approved by the College's Council, despite reservations voiced by COBUS President Ernesto G. Williams and several other Council Members. The student government held general forums in order to educate the student body on how this financial move would affect them, in addition to releasing information to the media on the matter (Campbell, 2013).

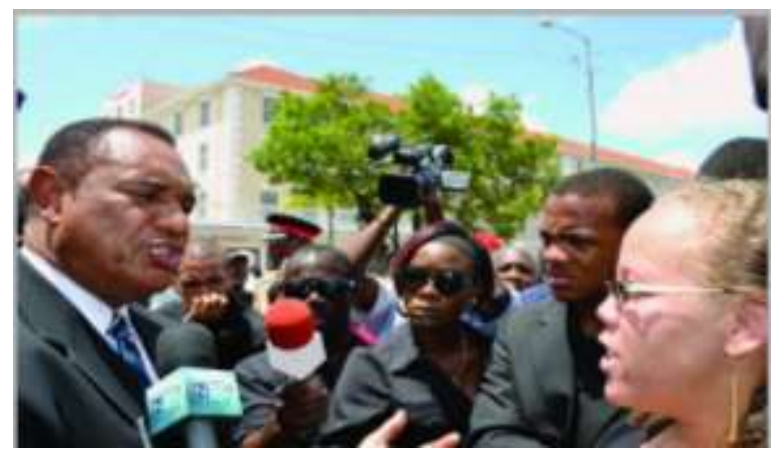

Source: Nassau Guardian, 2013

On April 17, 2013, police officers barred more than a dozen COB students from entering the House of Assembly on the grounds that it presented a security concern (Jones, 2013). Prime Minister Perry Christie spoke with the students after they had waited over four hours in Rawson Square. He stated that he was unaware of the fee increase. In February 2013, COBUS launched a public awareness initiative on the matter and held several forums for students as well publicized the concerns via social media.

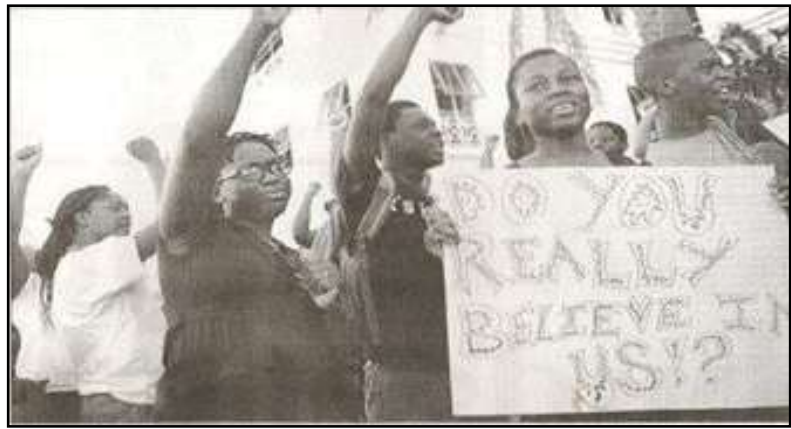

Source: Nassau Guardian, February 23, 2013 (Torrell Glinton).
After one of these open forums, students agreed to walk from the College to the Ministry of Education to speak with Education Minister Jerome Fitzgerald on this financial matter (Cartwright-Carroll, 2013). This demonstration took place on Wednesday February 20, 2013, which resulted in a meeting with the Minister the following day.

COBUS vocalized and publicized student concerns, and has had, in the main, a definitive presence. Former COBUS President Darron Cash led a riot in the late 80s (Expressing Feelings, 1986). On October 24th, 1986 students of the College staged a demonstration in front of the Churchill Building in downtown Nassau to protest the delay and cancellation of work permits for foreign lecturers hired by the College as per the directive of the Department of Immigration issued by the Minister Loftus Roker. This action on the part of students contributed to the implementation of a policy by the College, which stated that students had to complete their programme by the Spring semester in order to graduate in July of that year. (Dean, 1986)

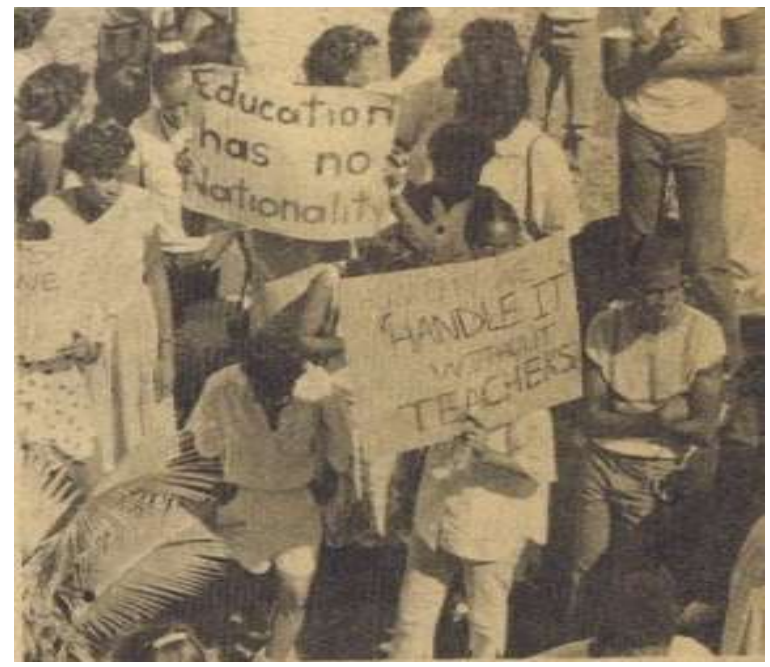

Source: The Spectrum, December 1986

The immigration issue resulted in a disruption in courses for over a month with repercussions being felt for much longer; however, the College offered students make-up classes to recoup their missed lectures and classwork. 
The College community collectively agreed that the immigration policy should have been dealt with in a more humane manner and without the unnecessary upheaval (Dean, 1986). President Cash questioned the commitment of the government to tertiary education and described the matter as not demonstrating "a commitment to education" (Turnquest, 1986).

Another matter of contention was the scheduling of final examinations on the Sabbath of Seventh Day Adventists. In an article in the Fall 1994 edition of The Spectrum, student Bridgette Wilkinson-Barrett wrote a series of letters requesting to take her final examination at an earlier time on Friday in the year 1990. However, these requests were denied. Ms. Wilkinson-Barrett did not sit the examination and thus received an $\mathrm{F}$; she later took the course again and received a $\mathrm{B}$ (Bowe, 1994).

Since the College's inception, the issue of crime has been a concern for all. While the matter of criminal activity on campus has been addressed at different times throughout the decades, it has never been completely resolved. In fact, among the spate of incidents on campus, there has even been a murder. In the 1980s Cynthia Tucker, a second year education student was discovered murdered near the dormitories. She was an active member of the Circle $\mathrm{K}$ group, which was the first student club formed on campus. Articles dated to the 80 s discuss a multitude of crimes against students including attempted rape and robbery. In an article dated December 1986 (Turnquest, Campus Security, 1986) proper training of security guards was suggested as a way to decrease the incidence of on-campus crimes. At that time, there were approximately 20 security officers, as compared to over 50 security officers, whose numbers have been supplemented by the hiring of external security officers.
Another way in which COBUS has demonstrated its commitment to improving student life at the College is through its involvement with Radio COB, which began as an idea advanced by a COBUS administrator. Radio COB, once a fully-functioning radio station, was launched by the College on November 2, 1987 with Michael Kirby as its general manager (Knowles, 1987). However, media regulations caused the station to have to close down. Although the College owns all the equipment and resources needed to run a radio station, many among the current student body, do not know that such an enterprise once existed.

A major challenge within the $\mathrm{COB}$ experience is the registration process, which is legendary - most students consider this to be a rite of passage. In the past, students had to join registration lines as early as 5:00 a.m. in order to register for courses. However, an April 1986 edition of The Spectrum reported that the College introduced a pre-registration process which greatly alleviated the registration problem (Miller, 1986). Then Registrar of the College, Dr. Roger Brown, noted in 1989, that computers would help the registration process and implemented their use in the fall of that year. Although registration by the Records Department has been computerized for some time, the online registration process was only implemented in the last decade.

While students today express their concerns about the lack of computers and printing resources, one must consider the advances that have been made in the years since the College first opened. In 1987, the College had only one computer center with only 36 microcomputers (Computer Centre, 1987). Although these numbers sound minimal, one must recall that in 1987, a computer cost thousands of dollars. It is clear that the College has always attempted to keep up with technology. While the use of computers was 
widespread in businesses, it was still a major accomplishment of the College to have had such resources back then.

Pageantry has also been a staple at the College with both Mr. and Ms. COB pageants being held. Although the events have not been held consistently, their past is rich. In the year 1986, for example, Scott Robinson took home the title of Mr. COB (For Guys Only, 1986). Although the "Ms COB" pageant has not been offered consistently, in the past the winner was awarded a scholarship as well as an opportunity to represent the country in international pageants.



Student athletes, circa 1985. Source: Author's personal archive

The College has seen a plethora of student groups over the years including the American Football group, the Circle K organization, the Drama Club, the Math Club, the Business Club, the Sports Club, the Student Christian Movement, the Education Awareness Society, the Agriculture club, Rotoract and the $\mathrm{COB}$ Union of Students (COBUS).

\section{COBUS}

The College of the Bahamas Union of Students, the official student government of COB, was brought to life by the student body with assistance from Dr John Knowles, the College's first Principal. In 1974 Dr Knowles visited an American university to learn about establishing student government at a tertiarylevel institution. The first COBUS elections were held in 1976 with Felix Rolle emerging as the winner. COBUS can be described as "the national amalgamation, voice, \& representation of all students at The College of The Bahamas". Operated by an Executive Board \& a Legislative Board totaling over 30 positions, COBUS is understood and identified as the sole agent and negotiator for all matters affecting the student body, as well as the training camp of budding leaders of change for in the nation's future. It operates under four statutes: democracy, governance, jurisdiction and advocacy.

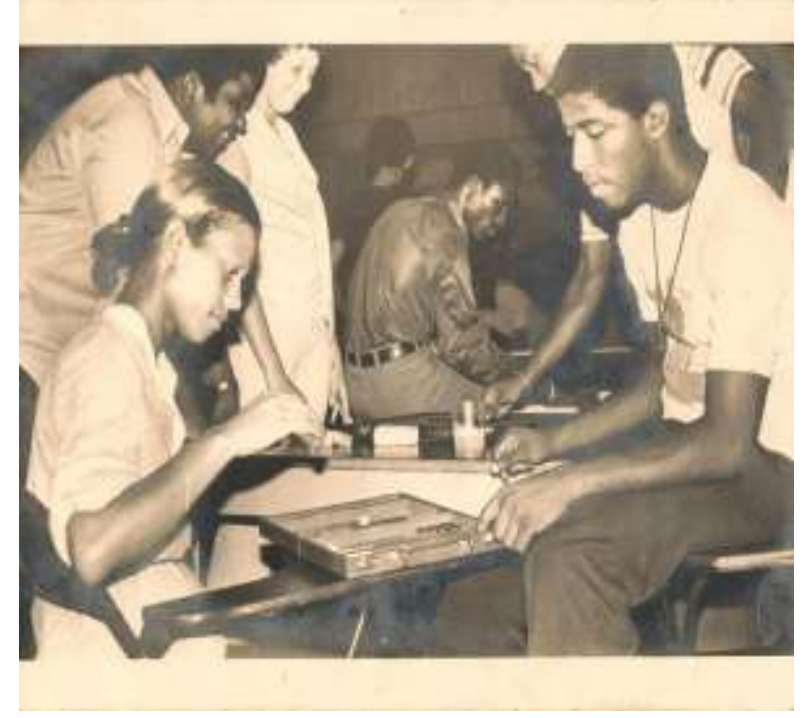

COBUS President Emeritus Felix Rolle in the background playing a board game. Source: Author's personal archive

During its almost 40 years of existence, the group has been an integral part of the existence of the College. The COBUS board is formed each Spring semester with an election in which the student body votes for their candidate of choice. Successful candidates form the student government, which has a term of one year.

This body has operated under a constitution for several decades but in the recent years, this governing document has been reviewed and 
revised extensively. In particular, during the Presidency of Antonio Butler Jr, the organization underwent major structural changes with the branch at the Northern Bahamas Campus being fully integrated into COBUS, allowing the organization to truly utilize its voice for the students of all campuses.

COBUS provides several forms of support not only the current and future student body of $\mathrm{COB}$, but also to the public at large. In addition to the many public forums and partnerships with both civil society and the government of The Bahamas, COBUS offers training for high school students through its annual Conference of Youth Leaders.

In addition to using its voice on the College Council, where the President serves as member, COBUS is active on campus and off campus through its assistance with national initiatives as well as smaller projects conducted by the many student groups on campus.

COBUS also works extensively with the Ministry of Youth, Sports \& Culture in addition to the Ministry of Education.

Throughout its existence, COBUS has produced some stellar leaders who have gone on to hold prominent positions within the wider Bahamian society. For instance, Melanie Griffith, who once ran for the position of COBUS President, is now a Member of Parliament and Minister of Social Services. Neil Ellis, former President, is the presiding Bishop for Global United Fellowship Ministries. COBUS leaders hold positions within government, religion, civil society, finance and beyond.

In their own way, whether it was during their time at the College or after completing their education, COBUS members continue to make an impact on their fellow Bahamians and on the nation as a whole.

It is important for students and Bahamians in general to know the history of the College and those who attended this prestigious institution. After all, as Confucius said, "Study the past if you would define the future." While the College writes its future, its past must be studied in order to ensure that the institution realizes its maximum potential, and that all of its constituents strive to live up to its motto, "Knowledge, Truth, Integrity."

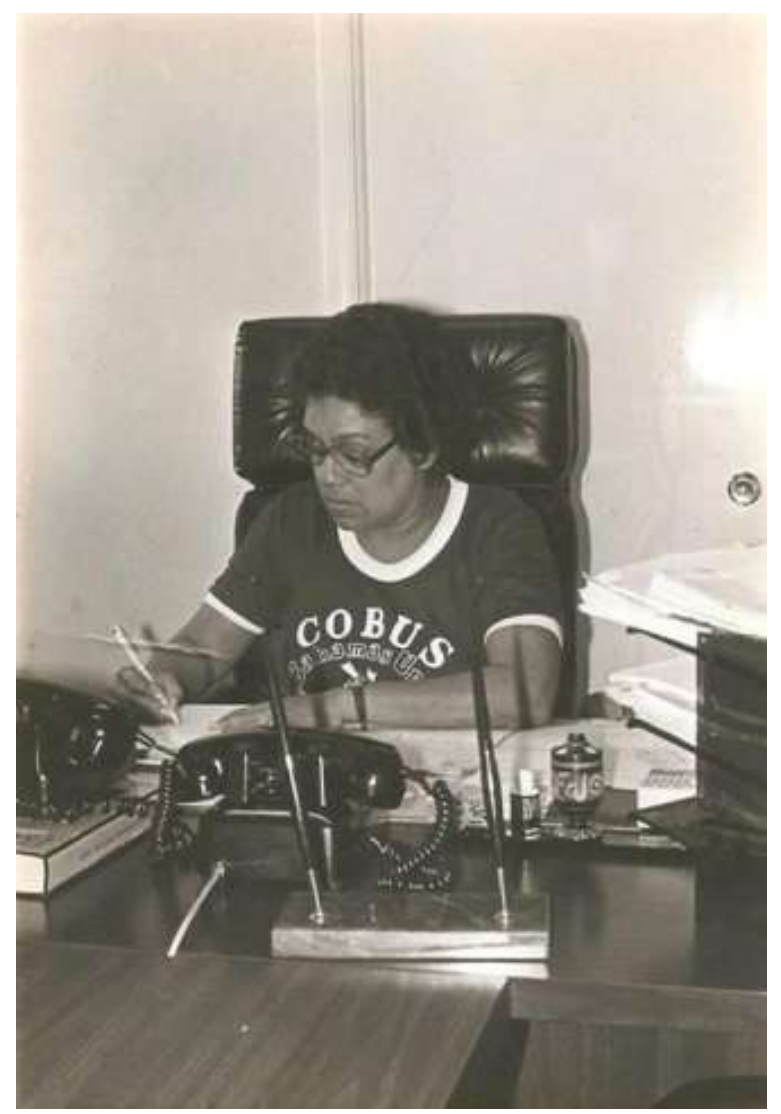

Dr Keva Bethel wearing a COBUS t-shirt. Source: Author's personal archive 
COBUS PRESIDENTS 1976-2014

\begin{tabular}{|l|l|}
\hline Felix Rolle II & $1976-1977$ \\
\hline Carl Darville & $1977-1978$ \\
\hline Robert Grant & $1978-1979$ \\
\hline Zendal Forbes & 1979 \\
\hline Neil Ellis & $1979-1981$ \\
\hline Zephaniah Francis & $1981-1982$ \\
\hline Terrence Bethel & $1982-1983$ \\
\hline Keod Smith & $1983-1984$ \\
\hline JoyAnne Ferguson & $1984-1985$ \\
\hline Zhivargo Laing & $1985-1986$ \\
\hline Darron Cash & $1986-1987$ \\
\hline lan Strachan & $1987-1988$ \\
\hline Tyrone Fitzgerald & $1988-1989 ?$ \\
\hline Robert K. Adams & $1989-1990$ \\
\hline Vincent Louis & $1990-1991$ \\
\hline Selvin Basden & $1991-1992$ \\
\hline Darren Lloyd & $1992-1993$ \\
\hline Ancella Evans-Williams & $1993-1994$ \\
\hline Troy Clarke & $1994-1995$ \\
\hline Clinton Rolle & $1995-1996$ \\
\hline Lee Trevino Deveaux & $1996-1997$ \\
\hline D'Addra Sturrup & $1997-1998$ \\
\hline Monique Saunders & $1998-1999$ \\
\hline Carolyn Rolle & $1999-2000$ \\
\hline Randol M. Dorsett & $2000-2001$ \\
\hline Danielle Hepburn & $2001-2002$ \\
\hline Jeremy Williams & $2002-2003$ \\
\hline Tavares Laroda & $2003-2004$ \\
\hline McKhale Taylor & $2004-2005$ \\
\hline Quinton Lightbourne & $2005-2006$ \\
\hline Kari Marcelle & Did not serve \\
\hline A'Leithia Sweeting & $2006-2007$ \\
\hline Anastarcia Huyler & $2007-2008$ \\
\hline Perry Newton & $2008-2009$ \\
\hline Jamaal Knowles & $2009-2010$ \\
\hline Antonio Butler II & $2010-2011$ \\
\hline Renbert Mortimer II & $2011-2012$ \\
\hline Alphonso W Major Jr. & $($ Interim) 2012 \\
\hline Ernesto Williams & $2012-2013$ \\
\hline Alphonso W. Major II & $2013-2014$ \\
\hline Matthew Kemp & \\
\hline
\end{tabular}

\section{REFERENCES}

Bowe, C. (1994, Fall). Adventists protest exam schedule. The Spectrum.

Campbell, A. (2013, February 23). The Nassau Guardian.

Cartwright-Carroll, T. (2013, February 21). COB students march on Ministry of Education. The Nassau Guardian.

Computer centre. (1987, December). The Spectrum, p. 8.

Davis, N. (1994, Spring). Her Majesty. The Spectrum.

Dean, C. (1986, December). Looking back to October. The Spectrum.

Expressing feelings. (1986, December). The Spectrum, p. 1.

Farmer, S. (2011, November 28). National profile: Dr. Gail Saunders. The Nassau Guardian.

For guys only. (1986, April). The Spectrum, p. 1.

Hall, E. (1996, Spring). Quiet strength. The Spectrum, p. 6.

Jones, R. (2013, April 18). COB students barred from House of Assembly. The Nassau Guardian.

Knowles, J. (1987, December). Radio COB is on air. The Spectrum, pp. 3, 8.

Miller, D. (1986, April). COB introduces preregistration. The Spectrum, p. 1.

Turnquest, L. (1986, December). Campus security. The Spectrum, p. 3.

Turnquest, L. (1986, December). Cash talks about job as COBUS's president. The Spectrum. 